\title{
Risk Appetite and Investment Behavior: A Study on Indonesia Muslim Investors
}

\author{
Egi Arvian Firmansyah ${ }^{1 *}$, Nirmala Andanawari \\ ${ }^{*}$ Corresponding author
}

\begin{abstract}
It has been nine years since the Indonesia Stock Exchange established a system called Syariah Online Trading System (SOTS), but the number of investors using this system is still relatively small compared to the regular investor. Moreover, the number is much smaller if it is compared to the potential number of sharia financial markets. This study aims to describe the behavior of Muslim investors in Indonesia who use the regular stock account instead of the sharia account. We surveyed by using both offline and online questionnaires, whereby the investors were asked to compose the imaginary stock portfolios consisting of stocks and their weights. Using a convenience sampling method, we succeeded in interviewing 85 respondents spread across Indonesia. The results of this study show that the risk appetite of Indonesian Muslim investors is risk-averse, and they consider sharia aspects in their investment decision. Nonetheless, the compliance to sharia varies among them. Hence, Indonesian Muslim investors cannot be seen and be treated as a homogenous group.
\end{abstract}

Keywords: investor behavior, Muslim investors, risk appetite, sharia compliance, stock market JEL Classification: G12, G15, G33

\begin{abstract}
Abstrak. Sudah menginjak tahun ke-sembilan semenjak Bursa Efek Indonesia meluncurkan sistem bernama Syariah Online Trading System (SOTS), namun jumlah investor syariah masih terhitung sangat sedikit bila dibandingkan dengan investor regular. Terlebih bila dibandingkan dengan potensi pasar keuangan syariah. Penelitian ini bertujuan untuk menggambarkan perilaku investor saham Muslim Indonesia yang menggunakan akun saham reguler. Kami melakukan survei menggunakan kuesioner daring dan luring kepada para investor. Investor diminta menyusun portofolio imajiner. Pengambilan sampel dilakukan dengan teknik convenience sampling dan kami mengumpulkan 85 responden dari berbagai daerah di Indonesia. Hasil penelitian menunjukkan bahwa preferensi risiko investor adalah risk averse, dan mereka memiliki pertimbangan terkait aspek kepatuhan terhadap pada aspek syariah dalam keputusan investasinya. Namun, seberapa patuh investor terhadap aturan syariah tersebut beragam. Maka dari itu, kelompok investor Muslim di Indonesia tidak dapat dipandang dan diperlakukan sebagai kelompok yang homogen.
\end{abstract}

Kata Kunci: pasar modal, perilaku investor, preferensi risiko, kepatuhan syariah, perilaku investor

\section{How to Cite:}

Firmansyah, E. A., \& Andanawari, N. (2020). Risk Appetite and Investment Behavior: A Study on Indonesia Muslim Investors. Etikonomi: Jurnal Ekonomi, 19(2), 287 - 298. https://doi.org/10.15408/etk.v19i2.16062. 


\section{Introduction}

Muslims believe that Islam does not only regulate the relationship between them with God but also encompasses the teaching to apply sharia (Islamic laws) in all aspects of life (Siddiqui, 1994). According to the State of Global Islamic Economy Report in 2018-2019, as reported by the Indonesian Ministry of National Development Planning (Bappenas, 2019), Muslim populations reached 1.84 billion people worldwide, and approximately 3 trillion U.S. dollars estimate to be spent in the sharia-compliant spending or consumption by all Muslims by 2023. In Indonesia, the growth of Islamic investment is partly triggered by the financial crisis and the support from Islamic institutions such as MUI (Indonesian Ulema Council) through the enaction of regulation or fatwa, allowing investors to comply with Islamic values conducting investment decisions (Amin, 2017).

Sharia-compliant investment is an investment in instruments, such as stocks, which follow Islamic rules. For a stock to be sharia-compliant, it has to follow both qualitative and quantitative criteria set by the government of a particular jurisdiction. Several previous studies have discussed the research on stock screening (Abdul Rahman et al., 2010; Bellalah et al., 2013; Derigs \& Marzban, 2008; Ho, 2015; Htay, Abedeen, \& Salman, 2013; Ibrahim, 2015).

In a more specific topic on investment behavior, Tahir \& Brimble (2011) conducted a study using an experimental design for comparing Muslim and non-Muslim investors in Brisbane, Australia. The sample of their study consists of 100 Muslims and 100 non-Muslim investors. They found that Islamic values affect the investment behavior of Muslim investors. However, the degree to which they affect behavior also influences the religiosity of each individual. Besides, among Muslim investors, they revealed wealth maximization behavior as in western investment behavior.

Other studies on Muslim investment behavior also conduct worldwide. Muhamad et al. (2006) show that religiosity level significantly affects Muslims' investment behavior in Malaysia. Nonetheless, the religiosity level can only explain the behavior by less than five percent. It also state that religion plays an essential role in investment decisions among Palestinian investors (Al-Afifi, 2013). When investing in foreign markets, Palestinian investors prefer sharia-compliant ones, such as financial assets in Arab countries.

Mansour \& Jlassi (2014) added that religion influences risk perception, behavior, and investment management by using a qualitative approach. Religious investors do not show the same behavior as non-religious ones. Religion does not only affect the risk level to be taken by investors but also investment behavior. Some investors avoid non-sharia instruments because they are afraid of doing sinful acts. Hence, it is evident that religion plays a pivotal role in composing a portfolio consisting of financial assets. As religion affects financial decisions and investment, it finally affects the capital structure and values owned by a company.

Conversely, by using the Malaysian case, Jamaludin (2013) showed that religiosity does not significantly affect investment decisions, primarily in the investment of pension funds. In Indonesia's context, that result is supported by Asytuti (2016), stipulating that religiosity of a Muslim does not guarantee that he or she will select a halal instrument in the capital 
market. This idea is supported by Shahzad et al. (2014), revealing that religion does not affect Pakistani Muslim investors' behavior. They showed that religion only accounts for $7.09 \%$ of the total influence, and it is a part of the cultural aspect. Thus, religiosity, according to their studies, does not significantly affect the investment decision. Besides, religiosity cannot use to predict decision making among investors.

The number of studies of Islamic investment behavior is relatively minimal, primarily the ones conducted in Indonesia. This present study aims to fill the literature gap by investigating the behavior of Indonesian Muslim investors who use the regular account (not a specific sharia account) when investing in the capital market, primarily in stocks. Hence, this study investigates whether or not Muslim investors consider sharia aspects of their investment decision. Besides, we investigate their investment preference, whether risk-averse, risk-neutral, or risk lover. To do this, we utilized both the closed-ended questions and open questions. These are several novelties of this present study hoping that we can contribute to the literature of Islamic investment behavior.

\section{Methods}

This study is descriptive research using data of Indonesian Muslim investors. The data were collected using both offline and online questionnaires. The questionnaire of this study consists of three sections (sections A, B, and C). Section A contains questions regarding the respondents' demography or profile covering the type of investment account (regular or sharia), age, sex, domicile, religion, income, and latest education level.

Section B comprises stocks' data whereby the investors are required to construct an imaginary portfolio from them. The investors ask to select five stocks with the fund's percentage or weight allocated to each stock. This section provided 24 stocks consisting of twelve Islamic stocks (included in ISSI) and twelve non-Islamic stocks (not included in ISSI but included in the LQ45 index). In addition to stock name or ticker, we provided other information of each stock, namely, three-month returns (August 2019 - November 2019), 12-month returns (November 2018 - November 2019), five-year returns (December 2013 - December 2018), five-year stock beta (December 2013 - December 2018) and sharia compliance status of each stock. We provided the beta data as the proxy of risk, which is the necessary information required to make investment decisions (Markowitz, 1952). The 24 stocks randomly select by omitting the stocks (companies) who conducted stock split (BBRI in 2017) and recorded an anomaly return (above 1000\%) due to reverse stock split (BRPT and HMSP).

Section $\mathrm{C}$ of our questionnaire consists of three open questions. The first question asks why the investors select particular stocks while the second one asks whether they consider beta in their portfolio construction. The third question asks whether they consider Islamic principles when selecting the stocks to be included in their portfolios.

The dissemination of an offline questionnaire was conducted in December 2019 to the participants of an event, namely, "training and sharing of early-stage investors in the Bandung region." Before we disseminated the questionnaire, we explained the mechanism 
for answering the questions in the questionnaire. So, the participants would have a better understanding of the technical aspect. Having been explained, the respondents then filled the questions in a maximum of 40 minutes. Finally, each respondent put the filled questionnaire in an envelope to guarantee confidentiality.

Direct interview conduct due to three reasons. First, it is understandable that a direct interview will let respondents answer the questions carefully. Besides, the complicated terminologies could be asked directly to the questionnaire administrator (Iselin et al., 2008). Second, the direct interview has proven to have a higher response rate as referring to Tahir \& Brimble (2011). Third, through a direct interview, we could obtain direct, spontaneous, and incidental responses to support and explain the empirical results (Mia \& Clarke, 1999).

Figure 1. Research framework

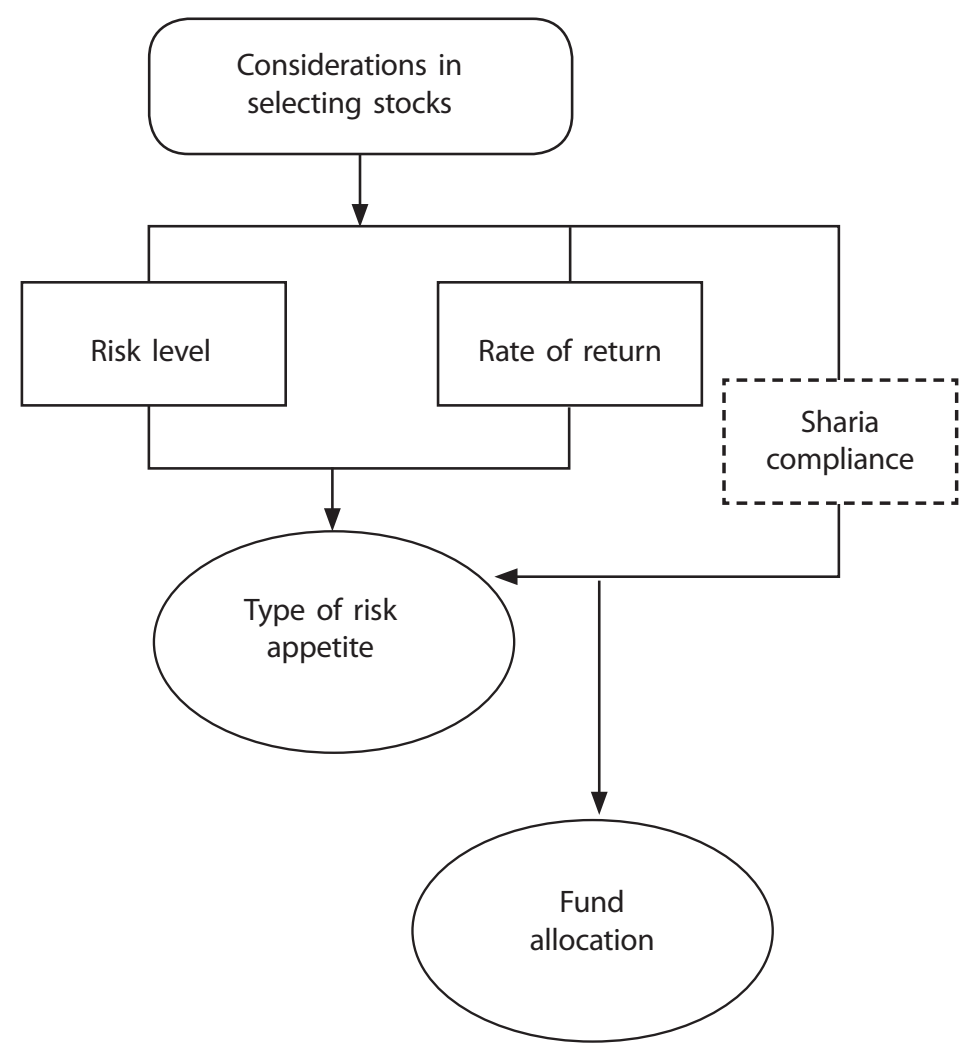

To obtain a broader range of respondents, we also disseminated an online questionnaire through Google Form in December 2019 until February 2020. The questionnaire link was sent through online media such as Instagram, Line, WhatsApp, and Twitter. We also shared the link to the investment community groups based in Bandung city and across Indonesia. The online questionnaire is superior for its speed and coverage (Kannan et al., 1998) and provides more flexibility so that the respondents can fill it at any time and place (Hogg, 2003). Finally, an online questionnaire is cost-efficient (Evans \& Mathur, 2005). This study's sampling technique is convenience sampling, allowing us to practically 
select respondents who are following specific criteria (Dornyei, 2007). Based on both offline and online questionnaire, we obtained answers from 148 investors across Indonesia. We then conducted selection by using several criteria, namely, Indonesian nationality, Islam by religion, and investors using the regular account. Finally, we obtained 85 usable questionnaires based on those criteria.

To attain the research objectives, we utilize descriptive statistics with the features as follows. First, we use the table of the frequency distribution for both the relative category and relative groups. The frequency distribution table for the relative category divides the observed data into several categories while the table of the frequency distribution for relative groups splits the observed data into interval classes. The interval classes are needed if the data category is numerous. Besides, the interval classes are shown in percentage to make it easier to understand.

Second, we utilize the minimum ( $\min$ ), and maximum ( $\max$ ) features to see the range of the observed data. The range is simply obtained by subtracting the max by the $\min \left(\mathrm{R}=\mathrm{x} \_\mathrm{t}-\mathrm{x} \_\mathrm{r}\right)$. Third, we also use the mean and standard deviation of the obtained data. Finally, the scatter diagram is used to portray the risk preference of the respondents in this study. This scatter diagram shows two axes where the $\mathrm{x}$-axis shows the risk while the y-axis shows the return. The research process in this study follows the framework in Figure 1 .

\section{Result and Discussion}

The final respondents of this study are 85 investors from various cities in Indonesia. The demography of those 85 investors shows in Table 1 . Table 1 shows that most of the respondents are young investors aged 18 to 26 years old (72\%). They are mostly male investors $(84 \%)$ and live in cities of West Java province (51\%). Most of them have a relatively small monthly income ranging from one to four million rupiahs (40\%). Most of the respondents are high school (41\%) and bachelor degree graduates $(41 \%)$ in terms of educational background. Therefore, we could summarize that most of our study respondents are young or early-stage Muslim investors.

Table 1. Demography of Respondents

\begin{tabular}{|c|c|c|}
\hline Variable & Frequency & Percentage \\
\hline \multicolumn{3}{|l|}{ Age } \\
\hline $18-26$ & 61 & $72 \%$ \\
\hline $27-35$ & 13 & $15 \%$ \\
\hline $36-45$ & 9 & $11 \%$ \\
\hline $46-55$ & 2 & $2 \%$ \\
\hline Total & 85 & $100 \%$ \\
\hline \multicolumn{3}{|l|}{ Sex } \\
\hline Male & 71 & $84 \%$ \\
\hline Female & 14 & $16 \%$ \\
\hline Total & 85 & $100 \%$ \\
\hline
\end{tabular}




\begin{tabular}{|c|c|c|}
\hline Variable & Frequency & Percentage \\
\hline \multicolumn{3}{|l|}{ Domicile } \\
\hline Jakarta & 7 & $8 \%$ \\
\hline Banten & 1 & $1 \%$ \\
\hline West Java & 43 & $51 \%$ \\
\hline Central Java & 11 & $13 \%$ \\
\hline East Java & 9 & $11 \%$ \\
\hline Yogyakarta & 1 & $1 \%$ \\
\hline Others (outside Java) & 13 & $14 \%$ \\
\hline Total & 85 & $100 \%$ \\
\hline \multicolumn{3}{|l|}{ Monthly Income } \\
\hline Less than IDR $1,000,000$ & 23 & $27 \%$ \\
\hline IDR $1,000,000$ to $4,000,000$ & 34 & $40 \%$ \\
\hline IDR $4,000,001$ to $7,000,000$ & 9 & $11 \%$ \\
\hline IDR $7,000,001$ to $10,000,000$ & 12 & $14 \%$ \\
\hline More than IDR 10.000 .000 & 7 & $8 \%$ \\
\hline Total & 85 & $100 \%$ \\
\hline \multicolumn{3}{|l|}{ Latest Education } \\
\hline High school & 35 & $41 \%$ \\
\hline Diploma & 7 & $8 \%$ \\
\hline Bachelor's degree & 35 & $41 \%$ \\
\hline Professional degree & 1 & $1 \%$ \\
\hline Master's degree & 7 & $8 \%$ \\
\hline Total & 85 & $100 \%$ \\
\hline
\end{tabular}

Source: processed data (2020)

Return and risk of the stocks selected by our respondents are measured by their mean, standard deviation, five-year return, and five-year beta as a proxy of risk. Table 2 shows the results of risk and return.

Table 2. Descriptive statistics of risk and return

\begin{tabular}{lcccccc}
\hline \multicolumn{1}{c}{ Variable } & N & Range & Minimum & Maximum & Mean & SD \\
\hline Five-Year Return & 85 & 8.81 & -0.71 & 8.10 & 1.51 & 2.19 \\
Five-Year Risk & 85 & 13.40 & -3.13 & 10.27 & 1.98 & 2.57 \\
\hline
\end{tabular}

Source: processed data (2020)

From Table 2, we can see that there are very few Muslim investors who selected stocks with negative returns $(-0.71)$, but most of them selected the stocks with a positive return. To obtain the portrayal of the stocks selected by investors, we mapped the 24 stocks into four scatter diagrams based on the closeness of those stocks to each other. Thus, relatively close stocks can make a particular pattern. 

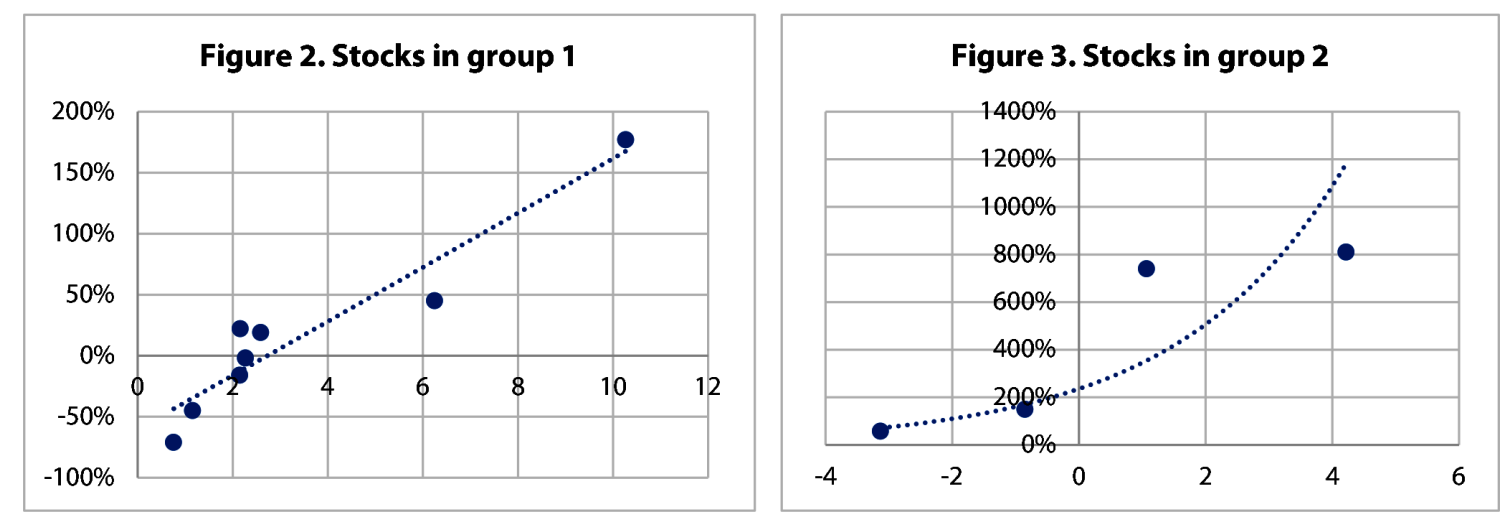

Source: processed data (2020)

Figure 3 shows the scatter diagram of risk and return consisting of eight stocks (ANTM, INDY, ITMG, JSMR, MEDC, MNCN, PGAS, WIKA) while Figure 4 shows the scatter diagram of other four stocks (ERAA, INKP, SRIL, TKIM). Figure 2 and Figure 3 show a positive relationship between the two variables (risk and return), as shown by the positively correlated line. This result is also similar to the case of other stocks selected by our research respondents, as shown in Figure 4 and Figure 5, as follows.
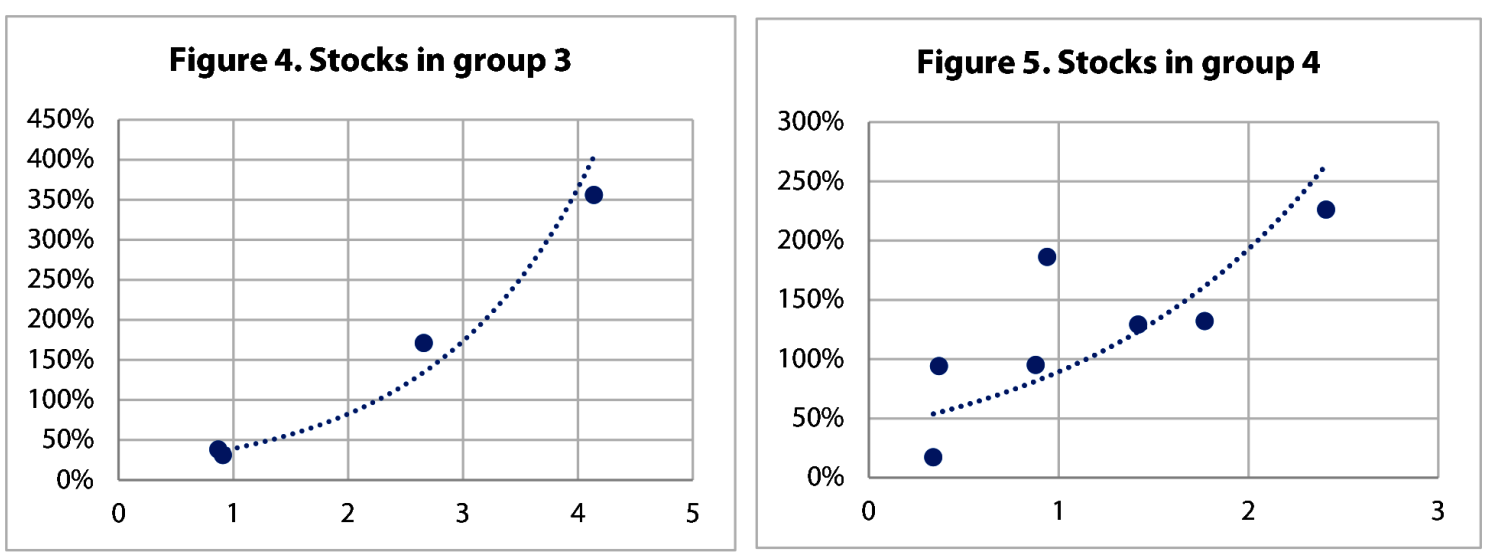

Source: processed data (2020)

Figure 4 shows the scatter diagram of risk and return of four stocks (ASII, BBNI, INDF, WSKT), while Figure 6 shows the scatter diagram of eight stocks (BBCA, BBTN, BMRI, GGRM, ICBP, JPFA, UNVR) selected by our respondents. Based on the four diagrams above, we can see that our study respondents have risk-averse behavior. Markowitz (1952) states that investors with risk-averse behavior will compile stock portfolios to obtain a certain level of return by accepting a certain level of risk. It can also be said that to get the desired rate of return, investors will accept the same risk as long as it is appropriately measured. Our respondents' risk-averse behavior indicates a possibility that there are considerations of sharia aspects in their investment decisions. As taught in the Holy Quran, Islam limits its adherents to participate in financial activities that are too high risk and do speculation or gambling practices (Bartke \& Schwarze, 2008). 
To further investigate the consideration of the sharia aspect in an investment decision, we identified the percentage of funds allocated in both sharia and non-sharia aspects by our respondents. As shown in Table 3, we can see that $70.96 \%$ of funds in all respondents' imaginary portfolio would be invested in sharia stocks. Besides, only $1.32 \%$ of our respondents would allocate their funds in the cigarette company, i.e., non-sharia compliant. Subsequently, Table 4 shows that $36.47 \%$ of respondents selected only the Islamic stocks (100\%) in their stock portfolio. The rest of the investors have varied compositions in the constructed portfolio. It shows that majority of respondents consider sharia aspects of establishing an investment portfolio. This result follows previous studies (Tahir \& Brimble, 2011; Muhamad et al., 2006; Al-afifi 2013; Mansour \& Jlassi, 2014; and Septyanto et al., 2017). The number of Islamic stocks included in a portfolio shows evidence that the compliance level among Muslim investors in Indonesia varies. This result supports the study of Tahir \& Brimble (2011). However, this study's finding differs from some earlier studies (Asytuti, 2016; Jamaludin, 2013; Shahzad et al., 2014).

Table 3. The asset allocation of Islamic stocks and non-Islamic ones

\begin{tabular}{|c|c|c|c|}
\hline Firm & Sector & $\mathbf{N}$ & Percentage \\
\hline \multicolumn{4}{|l|}{ Panel A: Sharia stocks } \\
\hline Aneka Tambang Tbk. (ANTM) & Mining & 19 & 6.271 \\
\hline Astra International Tbk. (ASII) & Miscellaneous industry & 20 & 6.601 \\
\hline Erajaya Swasembada Tbk. (ERAA) & Trading, service, and investment & 7 & 2.310 \\
\hline Indofoof CBP Sukses Makmur Tbk. (ICBP) & Consumer goods & 33 & 10.891 \\
\hline Indofood Sukses Makmur Tbk. (INDF) & Consumer goods & 16 & 5.281 \\
\hline Indo Tambangraya Megah Tbk. (ITMG) & Mining & 11 & 3.630 \\
\hline Japfa Comfeed Indonesia Tbk. (JPFA) & Basic industry and chemical substances & 17 & 5.611 \\
\hline Jasa Marga (Persero) Tbk. (JSMR) & Infrastructure, utility, and transportation & 10 & 3.300 \\
\hline Media Nusantara Citra Tbk. (MNCN) & Trading, service, and investment & 11 & 3.630 \\
\hline Perusahaan Gas Negara Tbk. (PGAS) & Infrastructure, utility, and transportation & 9 & 2.970 \\
\hline Unilever Indonesia Tbk. (UNVR) & Consumer goods & 43 & 14.191 \\
\hline Wijaya Karya (Persero) Tbk. (WIKA) & Property, real estate, \& building construction & 19 & 6.271 \\
\hline Total (Panel A) & & 215 & 70.96 \\
\hline \multicolumn{4}{|l|}{ Panel B: Non-sharia stocks } \\
\hline Bank Central Asia Tbk. (BBCA) & Finance & 28 & 9.241 \\
\hline Bank Negara Indonesia (Persero) Tbk. (BBNI) & Finance & 10 & 3.300 \\
\hline Bank Tabungan Negara (Persero) Tbk. (BBTN) & Finance & 2 & 0.660 \\
\hline Bank Mandiri (Persero) Tbk. (BMRI) & Finance & 7 & 2.310 \\
\hline Gudang Garam Tbk. (GGRM) & Consumer goods & 4 & 1.320 \\
\hline Indika Energy Tbk. (INDY) & Mining & 5 & 1.650 \\
\hline Indah Kiat Pulp \& Paper Tbk. (INKP) & Basic industry \& chemical substances & 7 & 2.310 \\
\hline Medco Energi Internasional Tbk. (MEDC) & Mining & 4 & 1.320 \\
\hline Semen Indonesia (Persero) Tbk. (SMGR) & Basic industry and chemical substances & 0 & 0 \\
\hline Sri Rejeki Isman Tbk. (SRIL) & Miscellaneous industry & 4 & 1.320 \\
\hline Pabrik Kertas Tjiwi Kimia Tbk. (TKIM) & Basic industry and chemical substances & 7 & 2.310 \\
\hline Waskita Karya (Persero) Tbk. (WSKT) & Property, real estate, and building construction & 10 & 3.300 \\
\hline Total (Panel B) & & 88 & 29.04 \\
\hline Total (Panel B) & & 292 & 100 \\
\hline
\end{tabular}

Source: processed data (2020) 
This qualitative result has resulted from the open-ended questions in our questionnaire. In terms of sharia compliance, $37 \%$ of respondents answered that the sharia aspect considers making a stock portfolio. It bases on several reasons. First, investors want to get tranquility in their investment, and second, they want to know the performance of those ethical companies. Third, they want to invest their fund in companies providing multi-benefits in society. This result indicates that religious values play a significant role in Muslim investors' investment activities, as has been found in Saudi Arabia (Almansour, 2019).

Table 4. Portfolio Consisting of Islamic Stocks

\begin{tabular}{lc}
\hline \multicolumn{1}{c}{ Islamic stocks } & Percentage of respondents \\
\hline Portfolio consisting of $<25 \%$ Islamic stocks & $2.35 \%$ \\
Portfolio consisting of $25 \%-50 \%$ Islamic stocks & $28.24 \%$ \\
Portfolio consisting of $51 \%-75 \%$ Islamic stocks & $25.88 \%$ \\
Portfolio consisting of $76 \%-99 \%$ Islamic stocks & $7.06 \%$ \\
Portfolio consisting of $100 \%$ Islamic stocks & $36.47 \%$ \\
\hline Total & $100 \%$ \\
\hline
\end{tabular}

Source: processed data (2020)

However, not all of our respondents answered that the sharia aspect is in their investment considerations. The number of investors answered so is $29 \%$. They perceived that the aspect of sharia is not essential and not need in constructing a portfolio. It is because sharia compliance does not affect the profitability of investment activities. This result demonstrates that several Muslim investors in Indonesia also follow the western style of investment; this also states in a previous study (Tahir \& Brimble, 2011). Our finding also shows that $34 \%$ of respondents had a lack of understanding of sharia. Some investors cannot differentiate clearly between the sharia and non-sharia stocks. They do not possess sufficient knowledge about the sharia aspects in selecting stocks.

From the open questions, we found that not all Muslim investors in Indonesia consider sharia compliance an essential variable in their investment decisions. Besides, their understanding of sharia varies from one to another. Although the sharia aspect is essential in a Muslim's investment, not all Muslim investors obey this principle. Moreover, they do not have adequate knowledge of sharia compliance. Therefore, we can summarize that Indonesian Muslim investors cannot treat as a homogeneous group.

As this result has several limitations, we provide some suggestions for further studies. Further research may increase the number of investors so that the result will be more informative. Further researchers may also use other experimental methods and compare between Muslim and non-Muslim investor groups and observe other financial investment opportunities, such as bitcoin, as has been recently conducted in Malaysia (Ayedh et al., 2020). 


\section{Conclusion}

This present study aims at identifying the behavior of Muslim investors in Indonesia. Based on the results of this study, we can conclude the following. First, the risk appetite of our respondents using regular accounts is risk-averse. It means that in constructing a portfolio, they are willing to pay more risk as long as a higher level of return compensates them. Second, in Indonesia, Muslim investors perceive that sharia compliance is an essential aspect of making a stock portfolio. However, the degree varies among them. Besides, some of the investors disobey the sharia aspect because it does not affect the return. Therefore, we can summarize that Indonesian Muslim investors cannot treat as a homogeneous group.

Based on the results of this study, we provide suggestions as follows. First, regulators and security companies need to hold more socialization and training sessions about the Islamic stock market. Social media can choose because people use it more intensively today. It expects that the Islamic financial literacy of Indonesian Muslims will improve. Furthermore, the approach that needs to be taken by security companies in targeting Indonesian Muslim investors should be accommodating. It means the current investment service, which provides regular and sharia accounts, is already on the track. It is because not all Indonesian Muslims will only select Islamic stocks in their investment decisions.

\section{References}

Abdul Rahman, A., Yahya, M. A., \& Nasir, M. H. M. (2010). Islamic Norms for Stock Screening. International Journal of Islamic and Middle Eastern Finance and Management, 3(3), 228-240. https://doi.org/10.1108/17538391011072426

Al-afifi, A. A. M. (2013). The Impact of Financial Literacy, Religious Belief, Brokerage Firms on Palestinian Investors' Behavior (Exploratory Study on the Individual Investors in the Gaza Strip). Journal for Humanities Sciences, 16(July). Retrieved from http://www. alazhar.edu.ps/journal123/human_Sciences.asp?typeno=0

Almansour, A. (2019). Muslim Investors and the Capital Market: The Role of Religious Scholars. Pacific Basin Finance Journal, 58, 101211. https://doi.org/10.1016/j. pacfin.2019.101211

Amin, M. (2017). Fatwa and The Development of Islamic Financial Industry: A Lesson From Indonesia. Al-Iqtishad: Journal of Islamic Economics: Jurnal Ilmu Ekonomi Syariah, 9(2), 331-350. https://doi.org/10.15408/aiq.v9i2.5353

Asytuti, R. (2016). The Impact of Religiousity To Preferences of Muslim's Investor In Capital Market. Jurnal Hukum Islam, 14(2), 115-133.

Ayedh, A., Echchabi, A., Battour, M., \& Omar, M. (2020). Malaysian Muslim Investors' Behaviour Towards the Blockchain-based Bitcoin Cryptocurrency market. Journal of Islamic Marketing, (In-press). https://doi.org/10.1108/JIMA-04-2019-0081

Bappenas. (2019). Indonesia Islamic Economic Masterplan 2019-2024. Indonesia Islamic Economic Masterplan 2019-2024. Jakarta: Bappenas. 
Bartke, S., \& Schwarze, R. (2008). Risk-Averse by Nation or by Religion? Some Insights on the Determinants of Individual Risk Attitudes. SOEPpapers on Multidisciplinary Panel Data Research, No. 131., 16.

Bellalah, M., Rehman, A. A., \& Masood, O. (2013). Syariah Compliant Screening Practices. Thema Working Paper N²013-16 Université de Cergy Pontoise, France.

Derigs, U., \& Marzban, S. (2008). Review and Analysis of Current Shariah-compliant Equity Screening Practices. International Journal of Islamic and Middle Eastern Finance and Management, 1(4), 285-303. https://doi.org/10.1108/17538390810919600

Dornyei, Z. (2007). Research Methods in Applied Linguistics. New York: Oxford University Press.

Evans, J. R., \& Mathur, A. (2005). The Value of Online Surveys. Internet Research, 15(2), 195-219. https://doi.org/10.1108/10662240510590360

Ho, C. S. . (2015). International Comparison of Shari'ah Compliance Screening Standards. International Journal of Islamic and Middle Eastern Financial Management, 8(2), 222245. https://doi.org/10.1108/IMEFM-07-2014-0065.

Hogg, A. (2003). Web Efforts Energize Customer Research. Electric Perspectives, 81-83.

Htay, S. N. N., Abedeen, Z., \& Salman, S. A. (2013). Towards Standardization of Shari'ah Screening Norms and Practices. International Journal of Humanities and Social Science Invention, 2(11), 23-30. Retrieved from http://www.ijhssi.org/papers/v2(11)/ Version-3/F021103023030.pdf

Ibrahim, M. H. (2015). Issues in Islamic Banking and Finance: Islamic Banks, Shari'ahCompliant Investment and Sukuk. Pacific-Basin Finance Journal, 34, 185-191. https:// doi.org/10.1016/j.pacfin.2015.06.002

Iselin, E., Mia, L., \& Sands, J. (2008). The Effects of the Balanced Scorecard on Performance: The Impact of the Alignment of the Strategic Goals and Performance Reporting. Journal ofGeneralManagement, 33(4), 71-85. https://doi.org/10.1177/030630700803300405.

Jamaludin, N. (2013). Religion and Individual Investment Choice Decision : The Case of Malaysia. International Journal of Social Science, 4(1), 104-113.

Kannan, P. K., Chang, A.-M., \& Whinston, A. B. (1998). Marketing Information on the I-Way: Data Junkyard or Information Gold Mine? Communications of the ACM, 41(3), 195-219.

Mansour, W., \& Jlassi, M. (2014). The Effect of Religion on Financial and Investing Decisions. In. Baker, H. K., \& Ricciardi, V (Eds). Wiley Finance Series. Investor Behavior: The Psychology of Financial Planning and Investing, 135-151. https://doi. org/10.1002/9781118813454.ch8

Markowitz, H. (1952). Portfolio Selection. The Journal of Finance, 7(1), 77-91. https://doi. org/10.1002/9781118267028.ch3.

Mia, L., \& Clarke, B. (1999). Market Competition, Management Accounting Systems and Business Unit Performance. Management Accounting Research, 10(2), 137-158. https:// doi.org/10.1006/mare.1998.0097 
Septyanto, D., Sudarwan, \& Dewanto, I. J. (2017). Model Behavior of Sharia Investment Decision on Muslim Investor in Indonesia Stock Exchange (IDX). International Journal of Economic Research, 14(4), 353-363.

Shahzad, S. K., Awan, H. M., \& Qureshi, A. S. (2014). Influence of Religion and Culture on Investment Behaviour of Muslim Investors in Pakistan. International Journal of Social Entrepreneurship and Innovation, 3(2), 85. https://doi.org/10.1504/ijsei.2014.064823.

Siddiqui, S. H. (1994). Islamic Banking. Karachi: Royal Book Company.

Tahir, I., \& Brimble, M. (2011). Islamic Investment Behaviour. International Journal of Islamic and Middle Eastern Finance and Management, 4(2), 116-130. https://doi. org/10.1108/17538391111144515. 